\title{
Is there a role for phenobarbital in palliative care: A systematic review
}

\section{ABSTRACT}

Introduction: Seizures are seen in $13 \%$ of cases in palliative care. Phenobarbital is a drug from the barbiturates' family most used for its anticonvulsant and sedative properties, and therefore the drug of choice in palliative care suitable for the management of seizures and agitation. The study aimed to evaluate the role of phenobarbital in palliative care settings.

Methods: A systematic literature review was conducted using predetermined keywords. Data was compiled and inclusion and exclusion criteria were established concerning the role of phenobarbital in palliative care. Five case studies met these criteria and were evaluated. Retrospective analysis of the data in the studies, along with randomized clinical trial about the use of at the end of life were reviewed by two independent reviewers.

Results: Results of this review showed that phenobarbital is efficacious in the management of seizures and agitation, can be easily administered via different routes and utilized in various palliative care settings. No serious adverse skin reactions were noted with the use of phenobarbital and it did not abruptly end a patient's life when used at appropriate doses.

Conclusions: Although phenobarbital is an old drug and is an approved anticonvulsant, its sedating properties make it to be useful not only for seizure management, but also in patients experiencing agitation, physical and psychological distress, and restlessness. More studies are warranted in the sole practice of using phenobarbital and further explore its role in palliative care.

Palliat Med Pract 2021; 15, 2: 163-171

Key words: phenobarbital, barbiturate, palliative care, seizure, end of life

\section{Introduction}

Many complications can arise in palliative care patients such as delirium, agitation, restlessness, and seizures. These states especially seizures and agitation can be very distressing, both to the patient and to the carers, and require active management. A convulsive episode in palliative care can be multifactorial: some being induced by the brain structure damage and the others may have a systemic origin. Examples of structural damage to the brain are primary tumours, metastases to the brain, abscesses, haemorrhage, reversible posterior leukoencephalopathy or radiation necrosis [1]. Seizures can be induced by the lack of oxygen (hypoxia), electrolyte abnormalities, such as hyponatremia, hypernatremia, hypomagnesemia, hypocalcaemia, hypercalcemia, hypoglycaemia, hyperglycaemia, uraemia and hepatic failure. Other causes of seizure activity can be related to medications side effects. For example, ondansetron, antipsychotics, and

\section{Address for correspondence:}

Helen Senderovich

Baycrest Health Sciences, 3560 Bathurst Street, M6A 2E1 Toronto, Canada

e-mail: hsenderovich@baycrest.org

Palliative Medicine in Practice $2021 ; 15,2,163-171$

Copyright (C Via Medica, ISSN 2545-0425, e-ISSN: 2545-1359

DOI: 10.5603/PMPI.2021.0011

This article is available in open access under Creative Common Attribution-Non-Commercial-No Derivatives 4.0 International (CC BY-NC-ND 4.0) license, allowing to download articles and share them with others as long as they credit the authors and the publisher, but without permission to change them in any way or use them commercially. 
chemotherapeutic drugs can act as a proconvulsant and lower the seizure threshold [2]. $13 \%$ of palliative care patients can develop seizure and phenobarbital is the most used drug to control it [2]. Seizures in palliative care occur most commonly in $25-50 \%$ of the patients who have brain metastases [2]. Of those cases, $25-45 \%$ of the patients have been presented with seizures at the time of diagnosis and the seizures progressed in severity with the cancer progression [2].

Glioblastoma multiforme is an aggressive rare primary brain tumour that has a poor prognosis despite the newer innovative treatment options. Phenobarbital is an optimal drug in the management of seizure and agitation due to its combined sedative and anticonvulsant properties. General indications for phenobarbital include sedation, management of generalized tonic-clonic, status epilepticus, and partial seizures. Off-label, it can be used for alcohol withdrawal and sedative/hypnotic withdrawal [8]. Subcutaneous (SC) phenobarbital in palliative care was approved by the Food and Drug Administration, however, is cautioned due to the possible adverse skin reactions [14]. Additionally, phenobarbital has been associated with somnolence, respiratory depression, and drug-drug interactions [14]. SC is widely used in palliative care especially in patients who are unable to take or tolerate oral medications [21].

Phenobarbital was synthesized first in 1911 by Hörlein and marketed by Bayer in 1912 under the trade name Luminal. Originally due to its hypnotic properties, it was trialled by Alfred Hauptmann in 1912 as an antiepileptic. Hauptmann concluded that Luminal was effective in the severest cases of epilepsy that were beyond the influence of even the heaviest doses of bromide [5]. According to the British Columbia Palliative Symptom Management Guidelines, the first-line therapy for seizure control is lorazepam [1]. Alternatively, midazolam, phenytoin, or valproic acid may be used. Uncontrollable status epilepticus can be managed with phenobarbital $120 \mathrm{mg} \mathrm{SC}$ or intravenous (IV) which can be titrated up to control the seizure as per recommended guidelines [1]. Physical and psychological agitation is very distressing, both for the patient and the family. It is important to achieve symptom control as quickly as possible. SC phenobarbital has been used to manage agitation, seizures and sedation purposes in palliative care patients as a last resort when the IV route is lost, due to its properties inhibiting the respiratory centre and augmenting the effect of benzodiazepines [14].

The study aimed to evaluate the role of phenobarbital in palliative care settings.

\section{Methods}

Two independent reviewers searched peer and non-peer-reviewed studies from MEDLINE, CENTRAL, Grey literature report, PubMed, Cochrane database and CINAHL for ("phenobarbital " or "phenobarbitone") and "palliative" and "seizure" with limits on the years from January 1991 to July 2017 . Eligibility assessment was performed by the independent reviewers and disagreements were resolved by consensus. Inclusion and exclusion criteria can be found in Table 1. The initial search yielded 41 potentially relevant studies. 18 were excluded based on the titles

Table 1. Inclusion and exclusion criteria for studies

\begin{tabular}{|c|c|c|}
\hline & Inclusion Criteria & Exclusion criteria \\
\hline Study Design & $\begin{array}{l}\text { - Randomized controlled trial, homogenous cohort study, retrospec- } \\
\text { tive analysis, and case note review } \\
\text { - Studies considered are between } 1991 \text { and } 2017 \text { in English langu- } \\
\text { age only } \\
\text { - Peer-reviewed and non-peer-reviewed studies } \\
\text { - Both statistically significant and non-significant studies }\end{array}$ & $\begin{array}{l}\text { - Studies conducted } \\
\text { before } 1991 \text { and after } \\
2016 \text { other than the } \\
\text { English language }\end{array}$ \\
\hline Population & $\begin{array}{l}\text { - Palliative care unit patients or resided in the community } \\
\text { - No age limit } \\
\text { - Patient with seizure activity }\end{array}$ & $\begin{array}{l}\text { - Patients not in palliative } \\
\text { care } \\
\text { - Patient with no seizure } \\
\text { activity }\end{array}$ \\
\hline Intervention & $\begin{array}{l}\text { - Phenobarbital used for seizure management at the end of life } \\
\text { - Different routes of administration i.e., subcutaneous, intravenous, } \\
\text { intramuscular, suppository, and micro enema forms } \\
\text { - Standard dosing was used }\end{array}$ & $\begin{array}{l}\text { - Phenobarbital used in } \\
\text { patients not at the end } \\
\text { of life }\end{array}$ \\
\hline Outcome & $\begin{array}{l}\text { - Efficacy of phenobarbital in management of end-of-life seizure as } \\
\text { monotherapy } \\
\text { - Most efficacious route of administration of phenobarbital in the } \\
\text { palliative care unit } \\
\text { - Incidence of adverse effects, e.g., site reaction, sedation }\end{array}$ & \\
\hline
\end{tabular}


Table 2. Literature review on the role of phenobarbital in management of seizures in palliative care patients

\begin{tabular}{|c|c|c|c|c|}
\hline $\begin{array}{l}\text { Authors, } \\
\text { year, } \\
\text { reference }\end{array}$ & $\begin{array}{l}\text { Study } \\
\text { Design }\end{array}$ & Population & Outcomes & Authors' Conclusions \\
\hline $\begin{array}{l}\text { Stirling, } \\
\text { Kurowska To- } \\
\text { okman (1999) } \\
{[1]}\end{array}$ & $\begin{array}{l}\text { Retrospecti- } \\
\text { ve analysis }\end{array}$ & $\begin{array}{l}60 \text { out of } 748 \text { PCU } \\
\text { patients were tre- } \\
\text { ated with pheno- } \\
\text { barbital in the last } \\
\text { week of life during } \\
3 \text { years }\end{array}$ & $\begin{array}{l}\text { Efficacy in psycho- } \\
\text { logical, and physical } \\
\text { agitation, and seizures, } \\
\text { number of as ne- } \\
\text { eded sedative agents } \\
\text { required during pheno- } \\
\text { barbital treatment }\end{array}$ & $\begin{array}{l}\text { Phenobarbital is an effective drug in } \\
\text { controlling agitation and seizures in } \\
\text { PCU patients }\end{array}$ \\
\hline $\begin{array}{l}\text { Lam, Lam and } \\
\text { Macy (2016) } \\
\text { [3] }\end{array}$ & $\begin{array}{l}\text { Randomised } \\
\text { controlled } \\
\text { trial }\end{array}$ & $\begin{array}{l}12 \text { healthy adu- } \\
\text { It subjects were } \\
\text { studied in } 3 \text { phases, } \\
\text { each phase lasting } \\
12 \text { hours. Between } \\
\text { each study phase } \\
1 \text {-month washout } \\
\text { period }\end{array}$ & $\begin{array}{l}\text { Absorption profile, } \\
\text { variability and tolera- } \\
\text { bility of phenobarbital } \\
\text { given in micro enema } \\
\text { suspensions vs suppo- } \\
\text { sitory }\end{array}$ & $\begin{array}{l}\text { Micro enema suspensions are supe- } \\
\text { rior to suppository. Macy catheter } \\
\text { (MC) suspension of } 6 \mathrm{ml} \text { (MC-6) } \\
\text { of water and MC suspension of } 20 \\
\mathrm{ml}(\mathrm{MC}-20) \text { water were used and } \\
\text { compared to suppositories. Mean } \\
\text { area under the curve (AUC) valu- } \\
\text { es of were higher for MC- } 20 \text { and } \\
\text { MC- } 6 \text { ( } 82 \% \text { ad } 46 \% \text { respectively) vs. } \\
\text { suppository (p < } 0.05 \%) \text {. There was } \\
\text { less variability in absorption of MC- } \\
20 \text { and MC- } 6 \text { ( } 1.4 \text {-fold to } 1.9 \text {-fold } \\
\text { difference) compared to } 4.4 \text {-fold } \\
\text { difference via suppository }\end{array}$ \\
\hline $\begin{array}{l}\text { Sykes and } \\
\text { Thorns (2003) } \\
\text { [4] }\end{array}$ & $\begin{array}{l}\text { Case note } \\
\text { review }\end{array}$ & $\begin{array}{l}5 \text { out of } 237 \text { PCU } \\
\text { patients were tre- } \\
\text { ated with pheno- } \\
\text { barbital } \\
\text { for } 4 \text { months } \\
\text { (January/1/1999- } \\
\text { April/30/1999) }\end{array}$ & $\begin{array}{l}\text { Sedation at the end } \\
\text { of life and impact on } \\
\text { survival }\end{array}$ & $\begin{array}{l}\text { Increases in a dose of phenobarbital } \\
\text { to achieve sedation in the last hours } \\
\text { of life were not associated with } \\
\text { overall shortened survival. Patients } \\
\text { that received a sedative dosage of } \\
\text { phenobarbital for less than } 48 \text { hours } \\
\text { had the shortest survival, whereas } \\
\text { patients that received a sedative } \\
\text { dose of phenobarbital the last } 7 \\
\text { days had a mean survival of } 36.6 \\
\text { days }(p<0.001)\end{array}$ \\
\hline $\begin{array}{l}\text { Pompili, Tele- } \\
\text { ra, Villani and } \\
\text { Pace (2014) } \\
{[6]}\end{array}$ & $\begin{array}{l}\text { Homogeno- } \\
\text { us cohort } \\
\text { study }\end{array}$ & $\begin{array}{l}30 \% \text { out of } 122 \\
\text { patients with } \\
\text { glioblastoma multi- } \\
\text { forme had epilepsy } \\
\text { over } 20 \text { months in } \\
2012-2013\end{array}$ & $\begin{array}{l}\text { Cost-effectiveness of } \\
\text { home palliative care }\end{array}$ & $\begin{array}{l}\text { Positive cost-effectiveness was seen } \\
\text { with at-home palliative care in } \\
\text { comparison to the cost of inpa- } \\
\text { tient hospice care in glioblastoma } \\
\text { multiforme patients. Phenobarbital } \\
\text { administered intramuscularly was } \\
\text { a drug of choice for the treatment } \\
\text { of seizures which occurred in } 30 \% \\
\text { of } 122 \text { patients with glioblastoma } \\
\text { multiforme }\end{array}$ \\
\hline $\begin{array}{l}\text { Hosgood, } \\
\text { Kimbre, } \\
\text { Protus and } \\
\text { Grauer (2014) } \\
\text { [7] }\end{array}$ & $\begin{array}{l}\text { Case note } \\
\text { review }\end{array}$ & $\begin{array}{l}69 \text { patients in PCU } \\
\text { case note review } \\
\text { was studied over } \\
36 \text { months }\end{array}$ & $\begin{array}{l}\text { Use of phenobarbital } \\
\text { for management of } \\
\text { refractory seizures } \\
\text { administered SC }\end{array}$ & $\begin{array}{l}\text { Two mild, grade } 1 \text { skin reaction out } \\
\text { of } 774 \text { distinct SC phenobarbital in- } \\
\text { jections were recorded in } 2.9 \% \text { of } 69 \\
\text { patients. } 0.3 \% \text { of SC phenobarbital } \\
\text { injections was noted to be tolerated } \\
\text { well }\end{array}$ \\
\hline
\end{tabular}

that did not meet the inclusion criteria. There were then 23 abstracts that were reviewed ranging from op-ed pieces, qualitative studies, randomized controlled trials (RCT), prospective cohort studies, as well as theoretical trial designs. Eight of these studies were excluded based on the study designs not meeting the inclusion criteria. Of these, 15 articles were fully evaluated, where 10 were excluded based on the study design and inclusion criteria not being met. Five studies were deemed to be useful and relevant to the objective at hand which included retrospective analysis of case notes, RCT and retrospective chart review. These articles were then read, and the relevant points and themes were summarized in Table 2. Corroborative themes were identified and the authors responsible for the contributing research were cited as they came up. Additional sources were added to the literature search by way of being referenced in the article. 


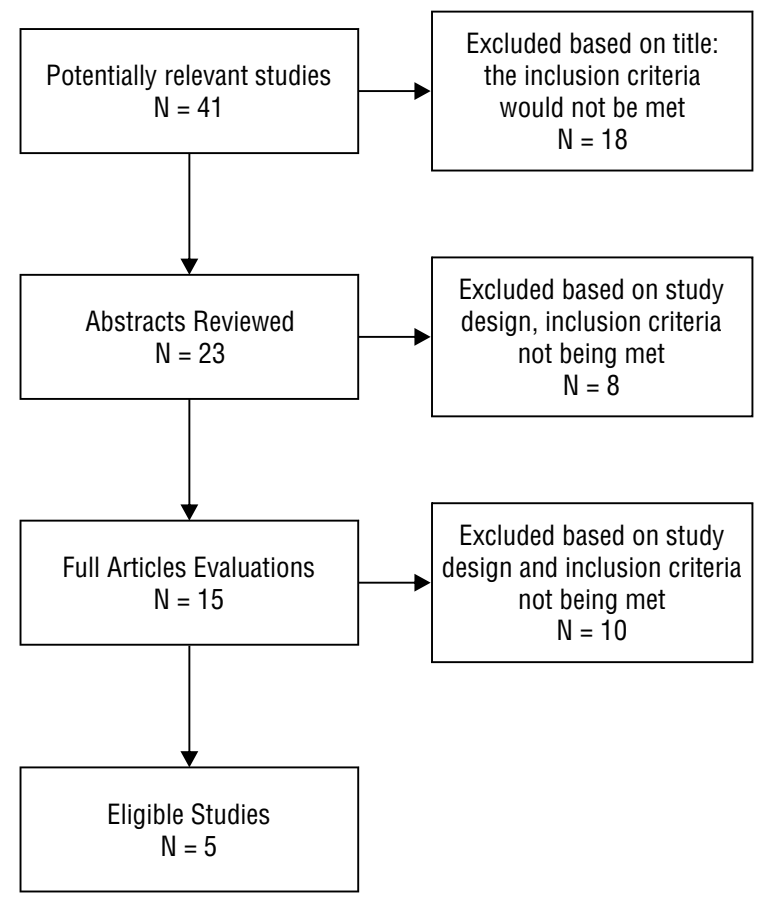

Figure 1. PRISMA flow diagram

\section{Results}

All selected and reviewed 5 studies confirmed the benefits of phenobarbital in palliative care. Stirling et al. conducted a retrospective analysis examining psychological, physical agitation and seizures in patients on palliative care unit (PCU) who received phenobarbital during the last week of life over 3 years. It was demonstrated that there was reduced agitation and cessation of future seizures in the phenobarbital group. It was concluded that phenobarbital was a reliable effective agent in controlling agitation and seizures at the end of life [1].

An open-label crossover RCT by Lam et al. studied the absorption profile, variability and tolerability of phenobarbital given in micro enema suspensions administered with a Macy catheter (MC), which was compared to suppositories in 12 healthy adult subjects. It was demonstrated that MC suspensions had higher AUC values and less variability compared to oral suppository confirming the greater efficacy of micro enema MC phenobarbital suspensions [3].

Risk of bias domains

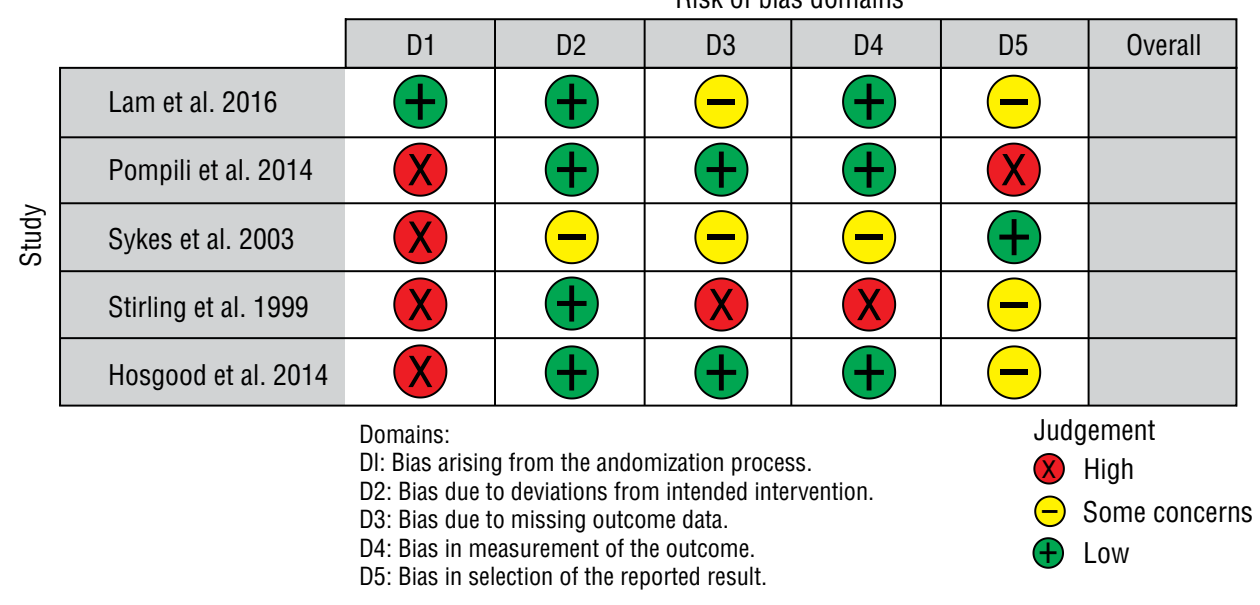

Bias arising from the randomization process Bias due to deviations from intended interventions

Bias due to missing outcome data Bias in measurement of the outcome Bias in selection of the reported result Overall risk of bias

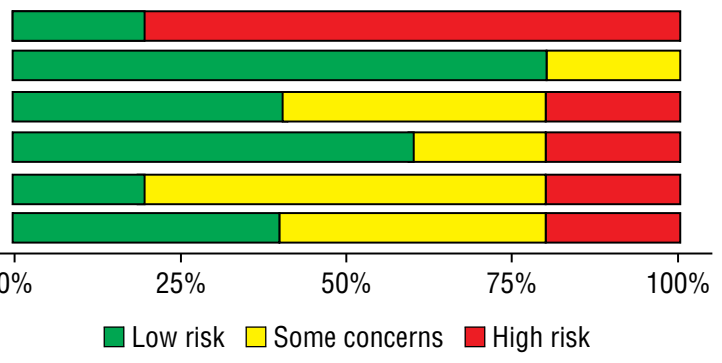

Figure 2. Risk of bias Table 
Sykes et al. conducted a case note review examining sedative properties of phenobarbital for PCU patients over 4 months. It was demonstrated that a higher sedative dose of phenobarbital over a shorter period was associated with the shortest survival compared to appropriate sedative dose concluding that appropriate dosage of phenobarbital was not associated with overall shortened survival [4].

Pompili et al. conducted a longitudinal study examining the cost-effectiveness of home assistance for patients with glioblastoma multiforme over 1 year. The study revealed that the cost-effectiveness of phenobarbital for seizure management was positively associated with at-home assistance, compared to in-patient hospice care, concluding that phenobarbital was the preferred drug of choice for patients with severe seizures receiving home palliative care [6].

A case note review conducted by Hosgood et al. examined the use of phenobarbital in palliative care for the management of refractory seizures by administering SC injections. The study concluded that SC phenobarbital injections did not provoke high-grade skin reactions [7]. A total of 134 palliative care patients treated with phenobarbital were analysed in 3 studies $[1,4,7]$.

\section{Risk of bias}

The studies that have met our criteria were mainly retrospective analysis of case notes, RCT and retrospective chart review. The GRADE tool was used to create a risk of bias table assessment which can be found in Table 1. The randomization procedure in the cross over study by Lam et al. was adequate concerning the age, gender, medical history, physical examination and standard lab panels, but the lack of follow up and high drop off rate from the study led to attrition bias which may have influenced the statistical power of the study and changed the characteristics of the groups [3]. In addition, the outcome of this study was not as thoroughly reported due to the small sample size similar to Hosgood et al. trial [7]. The study conducted by Pompili et al. concluded that phenobarbital was the drug of choice for severe seizure, but it covered only $30 \%$ of the cases in the study leading to weakened external validity and limiting the generalizability to the whole palliative care population [6]. The results of the Sykes et al. study was not representative as well, as the role of phenobarbital in seizure management was not solely examined [4]. Other sedative agents, such as midazolam and methotrimeprazine were included in the statistical analysis leading to results that were not exclusively attributed to phenobarbital alone. Furthermore, there was a lack of statistical analysis in most of the reviewed studies. Only Sykes et al. [4] and Lam et al. [3] studies reported p-values. As a result, a conclusion could not be drawn about the efficacy of phenobarbital. Stirling et al. utilized phenobarbital not only for seizures treatment but also for the management of agitation which may also confound the results about the efficacy of phenobarbital in seizure management [1].

\section{Discussion}

\section{Phenobarbital mechanism of action}

Phenobarbital is a well-known inducer of the cytochrome P450 system [11]. These enzymes are involved in the metabolism of many drugs that increases drug clearance. Specifically, phenobarbital has been shown to lower the plasma concentration of other antiepileptic drugs such as phenytoin and valproic acid by inducing the isoenzyme CYP3A4 [12]. A clinically important interaction occurs between phenobarbital and valproic acid. Valproic acid is a weak inhibitor of CYP3A4, and when coadministered with phenobarbital has been shown to increase plasma phenobarbital levels [13]. When administering valproic acid, a reduction in phenobarbital dosage by up to $80 \%$ may be required to avoid toxic drug effects [18]. Another important dru$g$-drug interaction occurs between phenobarbital and benzodiazepines such as midazolam and diazepam. Midazolam is also metabolized by CYP3A4, and when coadministered with phenobarbital causes an increase in midazolam clearance [19]. Phenobarbital has been shown to inhibit the respiratory centre, especially when given opioids or benzodiazepines such as midazolam [22]. It is important to consider these interactions when monitoring the dosage, to keep phenobarbital in the therapeutic range.

Molecularly, phenobarbital has been shown to block complex 1 , also known as nicotinamide adenine dinucleotide (NADH) activity in the electron transport chain [16]. This prevents the utilization of NADH as a substrate, which is important in mitochondrial function. Induced mitochondrial dysfunction from phenobarbital causes increased oxidative stress leading to cell death and lactic acidosis [17]. Lactic acidosis can be detected by lactate dehydrogenase plasma levels (LDH). A study conducted by Anderson et al. found a direct correlation between high levels of LDH and neurotoxicity induced by barbiturates such as phenobarbital [16]. When measuring lactate levels in patients, high levels of LDH can indicate tissue damage. Therefore, it should be cautioned that phenobarbital administration, in addition to tissue damage can be driving LDH levels. 


\section{Role of phenobarbital in palliative care}

Five of the reviewed studies confirmed the efficacy of phenobarbital in palliative care. A total of 146 patients were treated with phenobarbital across these reviews. The study conducted by Stirling et al. reviewed the notes of all patients who received phenobarbital during the last week of life over 3 years [1]. This data was compared with other patients who died on the unit during the same period. The efficacy of phenobarbital was assessed by retrospective analysis of the case notes and the concurrent prescribing of other sedative agents. In the group of patients for whom phenobarbital was prescribed, there was written evidence of its efficacy compared to other sedative drugs. There was no $p$-value or confidence interval available from this recent study as no statistical analysis was conducted. The notes of 60 patients in the last week of life who received SC or IM injections of phenobarbital with no significant difference between time from starting infusion by either route until death revealed that 27 patients received phenobarbital for agitation, 3 patients for psychological distress, 20 patients for agitation and psychological distress, and 9 patients for seizures. In the group for which seizures was the indication, no further seizures occurred after administration of phenobarbital [1]. No adverse cutaneous reactions were encountered [1].

The use of phenobarbital in palliative care has been shown to have concerns over sedative use and shortening survival (doctrine of double effect). Due to phenobarbital pharmacokinetic characteristics, recommendations for starting doses in a palliative situation do not exist, however, the application of lower doses (if necessary repeated), may be preferable over the initial use of the maximum recommended dose [12]. This was shown to be irrelevant in a case review of 237 patients done by Sykes et al. where 5 patients were treated with phenobarbital at the end of life [4]. It was confirmed that the dose of phenobarbital was increased in the last hours of life up to 200$500 \mathrm{mg} / 24 \mathrm{~h}$ to achieve sedation was not associated with overall shortened survival [4]. The group of patients that received phenobarbital as a sedative agent in appropriate doses for less than 48 hours had the shortest survival, compared to the group of patients that received phenobarbital for the same purpose for the last 7 days (greater than 48 hours) who had a mean survival of 36.6 days $(p<0.001)$ [4]. This showed that initiating phenobarbital at appropriate doses did not abruptly end the patient's life as it was given during the last 7 days of life. However, 1 patient treated with $200 \mathrm{mg}$ of SC phenobarbital died 6 hours later, it was suspected that phenobarbital contributed to the progression of pneumonia in a patient with pre-existing lung cancer [4].

Pompili et al. reviewed the role of home-assistance for patients with glioblastoma multiforme, between the years of 2012-2013 [6]. There were 197 patients with brain tumours, 122 patients suffered from glioblastoma multiforme, 64 had died and 54 were still receiving assistance. The condition of these patients was assessed periodically using the Barthel Index, Karnofsky Performance Scale, and Mini-Mental State Examination. The staff that cared for these patients consisted of 2 neurologists, 5 nurses, 2 psychologists, 3 rehabilitation therapists, and 1 social worker. As the patient's health deteriorated approaching the end of life, the intensity of care progressed accordingly. A total of 2838 home visits and 11,714 days of assistance led to 34 deaths at home, 22 at the hospice, and 8 at the hospital. Home assistance revealed a positive impact on caregivers and improvement in quality of life in $72 \%$ of the patients due to a supportive approach directed towards education around palliative care and alleviation of caregiver stress [6]. Patients' self-perception of quality of life was no longer measured in the last weeks due to significant cognitive impairment. Palliative sedation was done using midazolam in $11 \%$ of the cases to treat symptoms such as delirium, agitation, death rattle or refractory seizures. IM phenobarbital was the drug of choice for severe seizures which occurred in $30 \%$ of those patients [6].

The pharmacokinetic properties of phenobarbital have shown to have a beneficial effect in the treatment of severe refractory seizures. The open-label crossover RCT by Lam et al. recruited 12 healthy adults to study the phenobarbital concentration given to patients in micro enema [3]. Micro enema was administered using an MC with crushed phenobarbital $194.4 \mathrm{mg}$ oral tablets suspended in $20 \mathrm{ml}$ (MC-20) of water and $6 \mathrm{ml}$ (MC-6) of water. It was compared to an equal dose of phenobarbital in suppository form [3]. The comparison was done by assessing the early absorption profile of equal doses of phenobarbital in suppository vs. phenobarbital in MC- 6 and MC- 20 micro enema solutions [3]. The results showed the mean plasma concentrations of phenobarbital at 10 minutes were 12 times higher in MC-20 and 8 times higher in MC-6 compared to the suppository [3]. Mean AUC values were higher for MC-20 and MC-6 $(82 \%$ and $46 \%$ respectively) vs. suppository ( $<<0.05 \%$ ). It was also noted that there was less variability in absorption of MC-20 and MC-6 (1.4-fold to 1.9-fold difference) compared to 4.4-fold difference via a suppository [3]. This showed that phenobarbital oral tablets crushed and suspended in water, delivered to the patients 
using $\mathrm{MC}$ had greater efficacy and can be easily administered compared to the oral suppository. It was concluded that phenobarbital suppositories were unreliable and had delayed onset of action in the management of seizures and intractable suffering when compared to phenobarbital suspended in MC-20 and MC-6 which showed less variability, and higher plasma concentration [3].

Subcutaneous administration of phenobarbital is cautioned by the American Hospital Formulary Service due to possible skin reactions. A study conducted by Hosgood et al. evaluated 69 patients and 774 distinct SC phenobarbital injections [7]. Two reactions were reported ( $2.9 \%$ of patients, $0.3 \%$ of injections), and both were mild grade 1 reactions that did not interfere with further administration of phenobarbital [7].

Phenobarbital has been used as a secondary treatment to manage seizures, agitations and sedative purposes. The route of administration, however, has been studied extensively i.e., SC, micro enema, and IV. Each of the studies that have been reviewed found phenobarbital to be effective in controlling seizures and agitation regardless of the route of administration. Some clinicians consider phenobarbital a first-line palliative sedation medication, while others use it as a third-line option that provides sedation in cases of inadequate response to anxiolytic sedatives and/or methotrimeprazine. Phenobarbital has a long duration of action with a rapid onset, reportedly faster than midazolam. It can be administered IV, by continuous SC infusion, or intermittent subcutaneous injection. Phenobarbital antiepileptic properties may be of additional anticonvulsant value [18]. In summary, these studies examine the use of phenobarbital in palliative care. It shows phenobarbital is a reliable, effective agent in controlling agitations and seizures, and can be considered as a first-line drug.

\section{Approach to seizure management in different palliative care settings}

Patients that are in palliative care, have decisions to make based on the conditions they are in, and the choice of setting they would prefer to be in during their final stages in life. These include admission to hospital, hospice or home care. Those that suffer from delirium, agitation, restlessness and seizures require adequate symptoms control to achieve maximum comfort at this period. Benzodiazepines are often administered as early as possible to shorten the seizure length [19]. Midazolam has been used most widely and is the first line of a drug to treat delirium, agitation and seizure due to its anxiolytic, anticonvulsive and sedative properties, which can be given SC or IV.
If midazolam is not or only partially controlling the symptoms, phenobarbital may be added. However, there is concern around midazolam augmenting the effects of phenobarbital and increasing the frequency of delirium and respiratory failure [22]. Phenobarbital is a drug of choice and can be used in palliative sedation to manage otherwise uncontrollable symptoms at the required sedation level.

Patients that experience severe refractory seizures can be treated with phenobarbital SC or IV, which requires trained medical staff to administer. For patients that would prefer their setting to be at home, micro enema suspensions delivered via MC would be preferable over the oral route (which can be compromised depending on the current medical history) SC or IV. Suppository form of phenobarbital has also been used but its delayed response associated with administration, discomfort and lack of efficacy makes it a less favourable choice over micro enema suspensions. MC suspension of crushed phenobarbital tablets in $20 \mathrm{ml}$ of tap water (MC-20) yielded the highest concentration and efficacy compared to MC suspension in $6 \mathrm{ml}$ of tap water (MC-6), and suppository form [3]. MC micro enema would be ideal for palliative care patients suffering from severe seizures who would prefer to be at home during this time.

Many drugs are used to treat symptoms in palliative care patients. The sedative properties of these drugs have been extensively studied. These studies showed an important role of phenobarbital in the management of seizure. Using sedative drugs such as midazolam, levomepromazine (methotrimeprazine) and phenobarbital for sedation, delirium, agitation, restlessness and seizure in the last 7 days of life have shown not to abruptly end a patient's life. Determining the therapeutic dose of phenobarbital may be helpful in difficult situations to achieve adequate seizure control using different modes of administration such as IV, SC and micro enema. The drug concentrations can be measured through blood samples if needed to guide the clinicians in seizure management in the palliative care setting.

\section{Limitations}

Most of the studies used phenobarbital for seizure, agitation, restlessness and some for sedation in the last 48 hours of life and not solely for seizure management. Using phenobarbital in combination with other sedatives can impact the reported outcome on the efficacy of phenobarbital seizure control. To ensure all the available literature on phenobarbital in palliative care patients was evaluated, peer and non-peer-reviewed studies were screened. However, non-peer-reviewed studies have not undergone rigorous scrutiny to 
ensure high-quality studies, which may have limited the validity when comparing studies. Small study size, short or lack of follow-up without standardized reporting of the outcome poses a risk of bias in assessing the efficacy of phenobarbital in seizure management at palliative care patients. A lack of RCT hinders the ability to determine whether a cause-effect relationship exists between treatment with phenobarbital and the outcome. Without statistically significant results, conclusions about phenobarbital may not be substantiated. As the population included in the only RCT included 12 healthy adults, the efficacy of phenobarbital in controlling seizures in this study was not assessed [3].

\section{Conclusions}

Phenobarbital is a reliable and effective drug in the treatment of seizures and agitation. It is a cost-effective drug that has high potency in relieving symptoms in palliative care patients. Phenobarbital can be used when the oral route is lost, and IV access may not be available or desired. Phenobarbital can be used for the management of severe, multifactorial seizures. The variety of available route options (SC, IV, IM and micro enema suspensions), make the use of phenobarbital ideal for different palliative care settings. Although phenobarbital has a sedative property it was not shown to abruptly end a patient's life when used at appropriate doses. Phenobarbital can be utilized in palliative care for the management of delirium, agitation, restlessness, seizures and sedation purposes due to sedative and anticonvulsant properties.

However, it should be noted that the use of phenobarbital for the management of seizures and to induce sedation has not been extensively studied. The limited number of studies reviewed may be insufficient to generalize phenobarbital use to all scopes of palliative care. To capture all the frontline evidence on phenobarbital, peer-reviewed and non-peer-reviewed studies are needed to understand the full scope of the drug at the end of life. To minimize bias, statistically significant studies are needed to substantiate the efficacy of phenobarbital in palliative care. RCT with larger sample sizes and longer follow up are needed to evaluate the efficacy of phenobarbital in the management of seizure and agitation. By randomizing and targeting palliative care patients experiencing seizures and agitation due to various medical conditions and using the subject of all ages, in a minimum of a 2-year time may help to establish the role of phenobarbital in palliative care. A sample size of a minimum of 200 patients across different palliative care settings may help to assess the efficacy of different routes of phenobarbital administration i.e., subcutaneous, intravenous, and micro enema and determine if this mode of administration is truly effective in the treatment of seizures and agitation at the end of life. Clinicians, nurses and researchers can work together to prescribe, gather and evaluate the data to further assess the efficacy of phenobarbital. Addressing the existent gaps would help to advance the knowledge in the use of phenobarbital in palliative care patients.

\section{Acknowledgements}

The authors would like to acknowledge Nida Amatul MD, Nuzla Ameen MD and Ryan Johal MD for their contribution in writing and editing of this manuscript.

\section{Declaration of conflict of interests}

The authors declare that there is no conflict of interest.

\section{Funding}

None declared.

\section{References}

1. Stirling LC, Kurowska A, Tookman A, et al. The use of phenobarbitone in the management of agitation and seizures at the end of life. J Pain Symptom Manage. 1999; 17(5): 363-368, doi: 10.1016/s0885-3924(99)00006-8, indexed in Pubmed: 10355215.

2. Tradounsky G. Seizures in palliative care. Can Fam Physician. 2013; 59(9): 951-5, e401, indexed in Pubmed: 24029509.

3. Lam YW, Lam A, Macy B, et al. Pharmacokinetics of Phenobarbital in Microenema Via Macy Catheter Versus Suppository. J Pain Symptom Manage. 2016; 51(6): 994-1001, doi: 10.1016/j. jpainsymman.2015.12.339, indexed in Pubmed: 27112311.

4. Sykes N, Thorns A. Sedative use in the last week of life and the implications for end-of-life decision making. Arch Intern Med. 2003; 163(3): 341-344, doi: 10.1001/archinte.163.3.341, indexed in Pubmed: 12578515.

5. Yasiry Z, Shorvon SD. How phenobarbital revolutionized epilepsy therapy: the story of phenobarbital therapy in epilepsy in the last 100 years. Epilepsia. 2012; 53 Suppl 8: 26-39, doi: 10.1111/epi.12026, indexed in Pubmed: 23205960.

6. Pompili A, Telera S, Villani V, et al. Home palliative care and end of life issues in glioblastoma multiforme: results and comments from a homogeneous cohort of patients. Neurosurg Focus. 2014; 37(6): E5, doi: 10.3171/2014.9.FOCUS14493, indexed in Pubmed: 25434390.

7. Hosgood JR, Kimbrel JM, McCrate Protus B, et al. Evaluation of Subcutaneous Phenobarbital Administration in Hospice Patients. Am J Hosp Palliat Care. 2016; 33(3): 209-213, doi: 10.1177/1049909114555157, indexed in Pubmed: 25473092.

8. Griebling TL, Kachru N, Carnahan RM, et al. By the 2019 American Geriatrics Society Beers Criteria ${ }^{\circledR}$ Update Expert Panel, By the American Geriatrics Society 2015 Beers Criteria Update Expert Panel. American Geriatrics Society 2015 Updated Beers Criteria for Potentially Inappropriate Medication Use in Older Adults. J Am Geriatr Soc. 2015; 63(11): 2227-2246, doi: 10.1111/jgs.13702, indexed in Pubmed: 26446832. 
9. Waller DG, Sampson AP. Pharmacol Ther. 2018: 311-323, doi: 10.1016/b978-0-7020-7167-6.00023-3.

10. Kale R, Perucca E. Revisiting phenobarbital for epilepsy. BMJ. 2004; 329(7476): 1199-1200, doi: 10.1136/bmj.329.7476.1199, indexed in Pubmed: 15550407.

11. Czekaj P. Phenobarbital-induced expression of cytochrome P450 genes. Acta Biochim Pol. 2000; 47 (4): 10931105. PMID: 11996099.

12. Brodie MJ, Mintzer S, Pack AM, et al. Enzyme induction with antiepileptic drugs: cause for concern? Epilepsia. 2013; 54(1): 11-27, doi: 10.1111/j.1528-1167.2012.03671.x, indexed in Pubmed: 23016553.

13. Perucca E. Clinically relevant drug interactions with antiepileptic drugs. Br J Clin Pharmacol. 2006; 61(3): 246-255, doi: 10.1111/j.1365-2125.2005.02529.x.

14. Tradounsky G. Seizures in palliative care. Can Fam Physician. 2013; 59(9): 951-5, e401, indexed in Pubmed: 24029509.

15. Grönheit W, Popkirov S, Wehner T, et al. Practical Management of Epileptic Seizures and Status Epilepticus in Adult Palliative Care Patients. Front Neurol. 2018; 9: 595, doi: 10.3389/fneur.2018.00595, indexed in Pubmed: 30116217.

16. Anderson $C M$, Norquist $B A$, Vesce $S$, et al. Barbiturates induce mitochondrial depolarization and potentiate excitotoxic neuronal death. J Neurosci. 2002; 22(21): 9203-9209, indexed in Pubmed: 12417645.
17. Olszewska A, Szewczyk A. Mitochondria as a pharmacological target: magnum overview. IUBMB Life. 2013; 65(3): 273-281, doi: 10.1002/iub.1147, indexed in Pubmed: 23441041.

18. Wen $\mathrm{X}$, Wang JS, Kivistö KT, et al. In vitro evaluation of valproic acid as an inhibitor of human cytochrome $\mathrm{P} 450$ isoforms: preferential inhibition of cytochrome P450 2C9 (CYP2C9). Br J Clin Pharmacol. 2001; 52(5): 547-553, doi: 10.1046/j. 0306-5251.2001.01474.x, indexed in Pubmed: 11736863.

19. Favié LMA, Groenendaal F, van den Broek MPH, et al. on behalf of the PharmaCool study group. Phenobarbital, Midazolam Pharmacokinetics, Effectiveness, and Drug-Drug Interaction in Asphyxiated Neonates Undergoing Therapeutic Hypothermia. Neonatology. 2019; 116(2): 154-162, doi: 10.1159/000499330, indexed in Pubmed: 31256150.

20. Bush SH, Tierney S, Lawlor PG. Clinical Assessment and Management of Delirium in the Palliative Care Setting. Drugs. 2017; 77(15): 1623-1643, doi: 10.1007/s40265017-0804-3, indexed in Pubmed: 28864877.

21. Bartz L, Klein C, Seifert A, et al. Subcutaneous administration of drugs in palliative care: results of a systematic observational study. J Pain Symptom Manage. 2014; 48(4): 540-547, doi: 10.1016/j.jpainsymman.2013.10.018, indexed in Pubmed: 24766744.

22. Cheng $C$, Roemer-Becuwe $C$, Pereira J. When midazolam fails.J Pain Symptom Manage. 2002; 23(3): 256-265, doi: 10.1016/s08853924(01)00412-2, indexed in Pubmed: 11888723. 


\section{Czy jest miejsce dla fenobarbitalu w opiece paliatywnej — przegląd systematyczny}

Artykuł jest tłumaczeniem pracy: Senderovich H., Waicus S., Is there a role for phenobarbital in palliative care: A systematic review. Palliat. Med. Pract. 2021, tom 15, nr 2: 163-171.

Należy cytować wersję pierwotną.

\section{STRESZCZENIE}

Wstęp: Napady drgawkowe obserwuje się w przypadku 13\% pacjentów objętych opieką paliatywną. Fenobarbital jest lekiem z rodziny barbituranów, najczęściej stosowanym ze względu na działanie przeciwdrgawkowe i uspokajające, dlatego jest lekiem z wyboru w opiece paliatywnej odpowiednim do leczenia napadów drgawkowych i pobudzenia. Celem pracy była ocena roli fenobarbitalu w warunkach opieki paliatywnej. Metody: Przeprowadzono systematyczny przegląd piśmiennictwa z wykorzystaniem wcześniej ustalonych stów kluczowych. Zebrano dane i ustalono kryteria włączenia i wyłączenia do analizy roli fenobarbitalu w opiece paliatywnej. Pięć studiów przypadku spełniło wyznaczone kryteria i poddano je ocenie. Retrospektywna analiza danych z badań, wraz z randomizowanymi badaniami klinicznymi dotyczącymi stosowania fenobarbitalu u schyłku życia pacjentów, została poddana przeglądowi przez dwóch niezależnych recenzentów.

Wyniki: Wyniki niniejszego przeglądu wykazały, że fenobarbital jest skuteczny w terapii napadów drgawkowych i pobudzenia, może być bezproblemowo podawany różnymi drogami i wykorzystywany w różnych warunkach opieki paliatywnej. Nie odnotowano żadnych poważnych niepożądanych reakcji skórnych podczas stosowania fenobarbitalu. Lek nie powodował nagłego zgonu pacjenta, gdy był stosowany w odpowiednich dawkach.

Wnioski: Chociaż fenobarbital jest od dawna znanym lekiem o potwierdzonym działaniu przeciwdrgawkowym, jego właściwości uspokajające sprawiają, że jest on przydatny nie tylko w leczeniu napadów drgawkowych, ale także u pacjentów doświadczających pobudzenia oraz fizycznego i psychicznego cierpienia czy niepokoju. Wymagane jest przeprowadzenie dalszych badań nad stosowaniem fenobarbitalu w praktyce oraz dalsze zgłębianie jego roli w opiece paliatywnej.

Palliat Med Pract 2021; 15, 2: 172-181

Słowa kluczowe: fenobarbital, barbiturany, opieka paliatywna, napad drgawkowy, koniec życia

\section{Adres do korespondencji:}

Helen Senderovich

Baycrest Health Sciences, 3560 Bathurst Street, M6A 2E1 Toronto, Kanada

e-mail: hsenderovich@baycrest.org 
Wstęp

Istnieje wiele powikłań, które mogą wystąpić u chorych objętych opieką paliatywną, takich jak zespół majaczeniowy, pobudzenie, niepokój i napady drgawkowe. Stany te, zwłaszcza napady drgawkowe i pobudzenie, mogą być bardzo niepokojące, zarówno dla pacjenta, jak i dla jego opiekunów i wymagają leczenia. Napad drgawkowy w opiece paliatywnej może mieć podłoże wieloczynnikowe: część jest powodowana uszkodzeniem struktur mózgu, zaś inne mogą mieć pochodzenie ogólnoustrojowe. Przykładami uszkodzenia struktur mózgu są guzy pierwotne, przerzuty do mózgu, ropnie, krwotoki, zespół tylnej odwracalnej leukoencefalopatii czy martwica popromienna [1]. Napady drgawkowe mogą być wywołane przez brak tlenu (hipoksja), zaburzenia gospodarki elektrolitowej, takie jak: hiponatremia, hipernatremia, hipomagnezemia, hipokalcemia, hiperkalcemia, hipoglikemia, hiperglikemia, mocznica i niewydolność wątroby. Inne przyczyny występowania napadów drgawkowych mogą być związane z działaniami niepożądanymi leków. Na przykład ondansetron, leki przeciwpsychotyczne i chemioterapeutyki mogą wywoływać konwulsje i obniżać próg drgawkowy [2]. U $13 \%$ chorych objętych opieką paliatywną mogą wystąpić napady drgawkowe, a najczęściej stosowanym lekiem do ich kontrolowania jest fenobarbital [2]. Napady drgawkowe w opiece paliatywnej występują najczęściej, bo aż u 25-50\% chorych z przerzutami do mózgu [2]. Spośród tych przypadków u 25-45\% chorych w chwili rozpoznania choroby występowały napady drgawkowe, których nasilenie wzrastało wraz z rozwojem nowotworu [2].

Glejak wielopostaciowy jest agresywnym, rzadkim, pierwotnym guzem mózgu, w przypadku którego rokowanie jest niepomyślne dla chorego pomimo zastosowania nowych, innowacyjnych metod leczenia. Fenobarbital jest optymalnym rozwiązaniem w terapii napadów drgawkowych i pobudzenia ze względu na łączenie działania uspokajającego i przeciwdrgawkowego. Ogólne wskazania do stosowania fenobarbitalu obejmują uspokojenie, postępowanie lecznicze w uogólnionych napadach toniczno-klonicznych, stanach padaczkowych i napadach częściowych. Poza wskazaniami rejestracyjnymi lek może być również używany do leczenia objawów związanych z odstawieniem alkoholu lub leków uspokajających/nasennych [8]. Amerykańska Agencja ds. Żywności i Leków (FDA, Food and Drug Administration) zatwierdziła podskórne stosowanie fenobarbitalu w opiece paliatywnej, jednak należy zachować ostrożność ze względu na możliwość wystąpienia niepożądanych reakcji skórnych [14]. Ponadto fenobarbital może prowadzić do występowania senności, depresji oddechowej i wchodzić w interakcje z innymi lekami [14]. Przezskórne podawanie leków jest szeroko stosowane w opiece paliatywnej, zwłaszcza u chorych, którzy nie są w stanie przyjmować lub nie tolerują leków podawanych drogą doustną [21].

Fenobarbital został zsyntetyzowany po raz pierwszy w 1911 roku przez Hörleina i wprowadzony do obrotu przez firmę Bayer w 1912 roku pod nazwą handlową Luminal. Pierwotnie ze względu na swoje właściwości nasenne został poddany badaniom próbnym jako lek przeciwpadaczkowy przez Alfreda Hauptmanna w 1912 roku. Hauptmann stwierdził, że Luminal był skuteczny w najcięższych napadach padaczkowych, na które nie pomagały nawet największe dawki bromu [5]. Zgodnie z wytycznymi leczenia paliatywnego w Kolumbii Brytyjskiej (British Columbia Palliative Symptom Management Guidelines) lekiem pierwszego rzutu w ramach terapii napadów drgawkowych jest lorazepam [1]. W ramach alternatywy stosuje się również midazolam, fenytoinę lub kwas walproinowy. Niedający się powstrzymać stan padaczkowy można opanować, podając fenobarbital w dawce $120 \mathrm{mg}$ podskórnie lub dożylnie, który można miareczkować w celu opanowania napadu drgawkowego zgodnie z zaleceniami [1]. Fizyczne i psychiczne pobudzenie jest bardzo niepokojące, zarówno dla pacjenta, jak i dla jego rodziny. Ważne jest, aby jak najszybciej uzyskać kontrolę objawów. Fenobarbital podawany podskórnie jest stosowany w celu opanowania pobudzenia, napadów drgawkowych i uspokojenia chorych objętych opieką paliatywną, jako ostatnia deska ratunku w przypadku utraty drogi dożylnej, ze względu na swoje właściwości hamujące ośrodek oddechowy i nasilające działanie benzodiazepin [14].

Celem pracy była ocena roli fenobarbitalu w warunkach opieki paliatywnej.

\section{Metody}

Dwóch niezależnych recenzentów przeszukało recenzowane i nierecenzowane publikacje medyczne zamieszczone w bazach danych MEDLINE, CENTRAL, Grey Literature Report, PubMed, Cochrane i CINAHL pod kątem haseł („fenobarbital" lub „luminal”) oraz „opieka paliatywna” i „napad drgawkowy” w okresie od stycznia 1991 do lipca 2017 roku. Ocena kwalifikowalności została przeprowadzona przez niezależnych recenzentów, a spory zostały rozstrzygnięte w drodze konsensusu. Kryteria włączenia i wyłączenia z badania przedstawiono $\mathrm{w}$ tabeli 1. Wstępne wyszukiwanie doprowadziło do wytypowania 41 publikacji, które zdawały się odpowiadać profilowi poszukiwanych publikacji, jednak 18 prac wykluczono na podstawie tytu- 
Tabela 1. Kryteria włączenia i wyłączenia z badania

\begin{tabular}{|c|c|c|}
\hline & Kryteria włączenia & Kryteria wyłączenia \\
\hline Typ badania & $\begin{array}{l}\text { - Randomizowane badanie kliniczne z grupą kontrolną, jednorodne } \\
\text { badanie kohortowe oraz przegląd historii choroby } \\
\text { - Uwzględniono publikacje z lat 1991-2017 wyłącznie w języku angiel- } \\
\text { skim } \\
\text { - Publikacje recenzowane i nierecenzowane } \\
\text { - Zarówno prace istotne, jak i nieistotne ze statystycznego punktu } \\
\text { widzenia }\end{array}$ & $\begin{array}{l}\text { Prace nieanglojęzyczne } \\
\text { opublikowane przed } \\
1991 \text { lub po } 2016 \text { roku }\end{array}$ \\
\hline Populacja & $\begin{array}{l}\text { - Pacjenci oddziału opieki paliatywnej lub objęci opieką domową } \\
\text { - Brak ograniczeń wiekowych } \\
\text { - Pacjenci z napadami drgawkowymi }\end{array}$ & $\begin{array}{l}\text { - Pacjenci nieobjęci opie- } \\
\text { ką paliatywną } \\
\text { - Pacjent bez napadów } \\
\text { drgawkowych }\end{array}$ \\
\hline Interwencja & $\begin{array}{l}\text { - Fenobarbital stosowany w leczeniu napadów drgawkowych u schyłku } \\
\text { życia } \\
\text { - Różne drogi podania, tj. podskórna, dożylna, domięśniowa, czopki i } \\
\text { mikrowlewki doodbytnicze } \\
\text { - Zastosowane standardowe dawkowanie }\end{array}$ & $\begin{array}{l}\text { - Fenobarbital stosowany } \\
\text { u pacjentów, którzy nie } \\
\text { znajdują się u schyłku } \\
\text { życia }\end{array}$ \\
\hline Wynik & $\begin{array}{l}\text { - Skuteczność monoterapii fenobarbitalem w leczeniu napadów pa- } \\
\text { daczkowych u schyłku życia } \\
\text { - Najskuteczniejsza droga podawania fenobarbitalu pacjentom oddzia- } \\
\text { łów opieki paliatywnej } \\
\text { - Częstość występowania działań niepożądanych, np. reakcja w miejscu } \\
\text { podania, uspokojenie polekowe }\end{array}$ & \\
\hline
\end{tabular}

łów, które nie spełniały kryteriów włączenia. Następnie przeanalizowano streszczenia 23 prac, które obejmowały felietony, badania jakościowe, randomizowane badanie kliniczne z grupą kontrolną, prospektywne badania kohortowe oraz plany badań teoretycznych. Osiem prac wykluczono, ponieważ typ badania nie spełniał kryteriów włączenia. Następnie 15 artykułów poddano pełnej ocenie, z czego 10 wykluczono ze względu na typ badania oraz niespełnienie kryteriów włączenia do niniejszego badania. Pięć publikacji uznano za przydatne $\mathrm{i}$ istotne dla omawianego celu. Obejmowały one retrospektywną analizę historii choroby, randomizowane badanie kliniczne z grupą kontrolną i retrospektywny przegląd kart pacjentów. Artykuły te następnie przeanalizowano, a istotne punkty i główne zagadnienia podsumowano w tabeli 2 . Zidentyfikowano potwierdzające się zagadnienia, zaś nazwiska autorów prac były przytaczane w porządku, w którym się pojawiały. Dodatkowe źródła dodano do wyszukiwania literatury w związku z ich przytaczaniem w artykule.

\section{Wyniki}

We wszystkich 5 wybranych i przeanalizowanych badaniach potwierdzono korzyści ze stosowania fenobarbitalu w opiece paliatywnej. Stirling i wsp. przeprowadzili retrospektywną analizę dotyczącą psychologicznego i fizycznego pobudzenia oraz napadów drgawkowych u pacjentów przebywających na oddziale opieki paliatywnej, którzy otrzymywali fenobarbital w ostatnim tygodniu życia. Badanie obejmowało dane z 3 lat. Wykazano zmniejszenie pobudzenia i ustąpienie napadów drgawkowych w grupie leczonej fenobarbitalem. Stwierdzono, że fenobarbital jest niezawodnym, skutecznym środkiem w kontrolowaniu pobudzenia i napadów drgawkowych u schyłku życia [1].

W otwartym randomizowanym badaniu klinicznym z grupą kontrolną przeprowadzonym w układzie krzyżowym przez Lam i wsp. badano profil wchłaniania, zmienność i tolerancję fenobarbitalu podawanego w postaci zawiesiny doodbytniczej za pomocą cewnika, którą porównywano z czopkami u 12 zdrowych osób dorosłych. Wykazano, że zawiesiny podawane za pomocą cewnika charakteryzują się wyższymi wartościami pola powierzchni pod krzywą (AUC, area under the curve) i mniejszą zmiennością w porównaniu z czopkiem doustnym, co potwierdza większą skuteczność zawiesin fenobarbitalu podawanych doodbytniczo [3].

Sykes i wsp. przeprowadzili przegląd historii choroby, w którym badali działanie uspokajające fenobarbitalu u pacjentów oddziałów opieki paliatywnej w okresie 4 miesięcy. Wykazano w nim, że większa dawka uspokajająca fenobarbitalu w krótszym okresie wiązała się z najkrótszym przeżyciem w porównaniu z odpowiednią dawką uspokajającą. W podsumowaniu uznano, że odpowiednie dawki fenobarbitalu nie wiązały się generalnie ze skróceniem okresu przeżycia [4]. 
Tabela 2. Przegląd piśmiennictwa na temat roli fenobarbitalu w leczeniu napadów drgawkowych u chorych objętych opieką paliatywną

\begin{tabular}{|c|c|c|c|c|}
\hline $\begin{array}{l}\text { Autorzy, rok, } \\
\text { źródło }\end{array}$ & Typ badania & Populacja & Wyniki & Wnioski autorów \\
\hline $\begin{array}{l}\text { Stirling, Ku- } \\
\text { rowska } \\
\text { Tookman } \\
\text { (1999) } \\
{[1]}\end{array}$ & $\begin{array}{l}\text { Analiza } \\
\text { retrospek- } \\
\text { tywna }\end{array}$ & $\begin{array}{l}60 \text { z } 748 \text { chorych } \\
\text { oddziału opieki palia- } \\
\text { tywnej było leczo- } \\
\text { nych fenobarbitalem } \\
\text { w ostatnim tygodniu } \\
\text { życia w okresie } 3 \text { lat }\end{array}$ & $\begin{array}{l}\text { Skuteczność kontro- } \\
\text { lowania pobudzenia } \\
\text { psychicznego, fi- } \\
\text { zycznego i napadów } \\
\text { drgawkowych, liczba } \\
\text { potrzebnych środków } \\
\text { uspokajających pod- } \\
\text { czas leczenia fenobar- } \\
\text { bitalem }\end{array}$ & $\begin{array}{l}\text { Fenobarbital jest skutecznym le- } \\
\text { kiem w kontrolowaniu pobudzenia } \\
\text { i napadów drgawkowych u pacjen- } \\
\text { tów oddziałów opieki paliatywnej }\end{array}$ \\
\hline $\begin{array}{l}\text { Lam, Lam and } \\
\text { Macy (2016) } \\
\text { [3] }\end{array}$ & $\begin{array}{l}\text { Randomizo- } \\
\text { wane bada- } \\
\text { nie kliniczne } \\
\text { z grupą } \\
\text { kontrolną }\end{array}$ & $\begin{array}{l}12 \text { zdrowych osób } \\
\text { dorosłych wzięło } \\
\text { udział badaniach } \\
\text { obejmujących } 3 \text { fazy, } \\
\text { każda faza trwała } \\
12 \text { godzin. Pomiędzy } \\
\text { każdą fazą badania } \\
\text { następował miesięcz- } \\
\text { ny okres pozbywania } \\
\text { się z ustroju uprzed- } \\
\text { nio stosowanego leku }\end{array}$ & $\begin{array}{l}\text { Profil wchłaniania, } \\
\text { zmienność i tolerancja } \\
\text { fenobarbitalu poda- } \\
\text { wanego w zawiesinie } \\
\text { doodbytniczej lub } \\
\text { w czopkach }\end{array}$ & $\begin{array}{l}\text { Stosowanie zawiesiny doodbytni- } \\
\text { czej daje lepsze wyniki terapeutycz- } \\
\text { ne niż czopki. Stosowano zawiesi- } \\
\text { ny podawanej cewnikiem - } \\
\text { w } 6 \text { ml i } 20 \text { ml wody w porównano } \\
\text { z czopkami. Średnie wartości AUC } \\
\text { były wyższe dla zawiesiny w } 20 \text { ml } \\
\text { i } 6 \text { ml wody (odpowiednio } 82 \% \\
\text { i } 46 \% \text { ) w porównaniu z czopkiem } \\
\text { (p < 0,05\%). Stwierdzono mniejszą } \\
\text { zmienność wchłaniania zawiesin } \\
\text { w } 20 \text { i } 6 \text { ml wody (1,4-krotna } \\
\text { różnica do 1,9-krotnej różnicy) } \\
\text { w porównaniu z 4,4-krotną różnicą } \\
\text { przy podawaniu leku w czopkach }\end{array}$ \\
\hline $\begin{array}{l}\text { Sykes and } \\
\text { Thorns (2003) } \\
{[4]}\end{array}$ & $\begin{array}{l}\text { Przegląd } \\
\text { historii cho- } \\
\text { roby }\end{array}$ & $\begin{array}{l}5 \text { spośród } 237 \\
\text { pacjentów oddziału } \\
\text { opieki paliatywnej } \\
\text { było leczonych feno- } \\
\text { barbitalem } \\
\text { w okresie } 4 \text { miesięcy } \\
\text { (od } 1 \text { stycznia 1999 } \\
\text { do } 30 \text { kwietnia 1999) }\end{array}$ & $\begin{array}{l}\text { Uspokojenie lekowe } \\
\text { u schyłku życia i jego } \\
\text { wpływ na przeżycie }\end{array}$ & $\begin{array}{l}\text { Zwiększanie dawki fenobarbitalu } \\
\text { w celu uzyskania uspokojenia } \\
\text { lekowego w ostatnich godzinach } \\
\text { życia nie wiązało się z reguły ze } \\
\text { skróceniem przeżycia. Pacjenci, } \\
\text { którzy otrzymywali uspokajającą } \\
\text { dawkę fenobarbitalu przez mniej } \\
\text { niż } 48 \text { godzin charakteryzowali } \\
\text { się najkrótszym okresem przeży- } \\
\text { cia, podczas gdy pacjenci, którzy } \\
\text { otrzymywali uspokajającą dawkę } \\
\text { fenobarbitalu przez ostatnie } 7 \text { dni } \\
\text { cechowali się średnim przeżyciem } \\
\text { wynoszącym } 36,6 \text { dni (p < 0,001). }\end{array}$ \\
\hline $\begin{array}{l}\text { Pompili, Tele- } \\
\text { ra, Villani and } \\
\text { Pace (2014) } \\
\text { [6] }\end{array}$ & $\begin{array}{l}\text { Jednorodne } \\
\text { badanie } \\
\text { kohortowe }\end{array}$ & $\begin{array}{l}\text { U } 30 \% \text { spośród } 122 \\
\text { chorych na glejak } \\
\text { wielopostaciowy wy- } \\
\text { stępowały epilepsje } \\
\text { przez } 20 \text { miesięcy } \\
\text { w latach } 2012-2013\end{array}$ & $\begin{array}{l}\text { Opłacalność domowej } \\
\text { opieki paliatywnej }\end{array}$ & $\begin{array}{l}\text { Zaobserwowano opłacalność } \\
\text { domowej opieki paliatywnej } \\
\text { w porównaniu z kosztami stacjo- } \\
\text { narnej opieki hospicyjnej u chorych } \\
\text { na glejaka wielopostaciowego. } \\
\text { Fenobarbital podawany domię- } \\
\text { śniowo był lekiem z wyboru w } \\
\text { leczeniu napadów drgawkowych, } \\
\text { które wystąpiły u 30\% spośród } 122 \\
\text { pacjentów z glejakiem wieloposta- } \\
\text { ciowym }\end{array}$ \\
\hline $\begin{array}{l}\text { Hosgood, } \\
\text { Kimbre, } \\
\text { Protus and } \\
\text { Grauer (2014) } \\
\text { [7] }\end{array}$ & $\begin{array}{l}\text { Przegląd } \\
\text { historii cho- } \\
\text { roby }\end{array}$ & $\begin{array}{l}\text { Analizie poddano } 69 \\
\text { pacjentów przeby- } \\
\text { wających na oddziale } \\
\text { opieki paliatywnej w } \\
\text { okresie } 36 \text { miesięcy }\end{array}$ & $\begin{array}{l}\text { Zastosowanie feno- } \\
\text { barbitalu podawa- } \\
\text { nego przezskórnie } \\
\text { w leczeniu opornych } \\
\text { na leczenie napadów } \\
\text { drgawkowych }\end{array}$ & $\begin{array}{l}\text { Dwie łagodne reakcje skórne } \\
\text { (I stopnia) na } 774 \text { iniekcji podskór- } \\
\text { nych fenobarbitalem odnotowano } \\
\text { u 2,9\% z } 69 \text { pacjentów. Natomiast } \\
\text { 0,3\% iniekcji podskórnych było } \\
\text { dobrze tolerowanych }\end{array}$ \\
\hline
\end{tabular}


Pompili i wsp. przeprowadzili badanie podłużne, w którym analizowali opłacalność opieki w domu

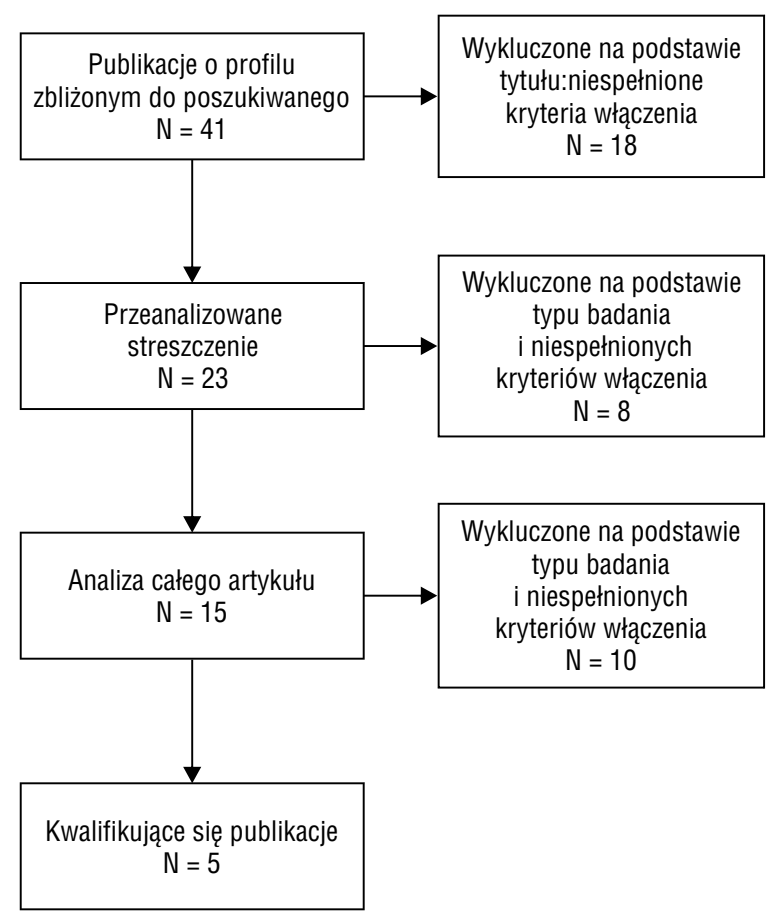

Rycina 1. Diagram przepływu PRISMA pacjentów z glejakiem wielopostaciowym w okresie jednego roku. W badaniu tym wykazano, że opłacalność fenobarbitalu w leczeniu napadów drgawkowych była pozytywnie związana z opieką w domu w porównaniu z opieką hospicyjną w warunkach stacjonarnych, stwierdzając, że fenobarbital jest preferowanym lekiem z wyboru u chorych z ciężkimi napadami drgawkowymi objętych domową opieką paliatywną [6].

Hosgood i wsp. w przeglądzie historii choroby przeanalizowali zastosowanie fenobarbitalu podawanego podskórnie w opiece paliatywnej w zakresie opornych na leczenie napadów drgawkowych. W badaniu tym stwierdzono, że podskórne iniekcje fenobarbitalu nie wywołują poważnych reakcji skórnych [7]. W trzech badaniach [1, 4, 7] przeanalizowano łącznie przypadki 134 chorych leczonych fenobarbitalem w ramach opieki paliatywnej.

\section{Ryzyko błędu systematycznego}

Badaniami, które spełniły nasze kryteria, stanowiły głównie retrospektywne analizy historii choroby, randomizowane badania kliniczne z grupą kontrolną i retrospektywny przegląd kart pacjentów. Narzędzie GRADE zostało wykorzystane do stworzenia tabeli oceny ryzyka błędu systematycznego (zob. tab. 1). Procedura randomizacji w badaniu krzyżowym Lam

Domeny ryzyka błędu systematycznego

\begin{tabular}{|c|c|c|c|c|c|c|}
\hline & \multicolumn{6}{|c|}{ Domeny ryzyka błędu systematycznego } \\
\hline & D1 & $\mathrm{D} 2$ & D3 & D4 & D5 & Ryzyko \\
\hline \multicolumn{7}{|l|}{ Lam i wsp. (2016) } \\
\hline \multicolumn{7}{|l|}{ Pompili i wsp. (2014) } \\
\hline \multicolumn{7}{|l|}{ Sykes i wsp. (2003) } \\
\hline \multicolumn{7}{|l|}{ Stirling i wsp. (1999) } \\
\hline \multicolumn{7}{|l|}{ Hosgood i wsp. (2014) } \\
\hline & \multicolumn{6}{|c|}{$\begin{array}{l}\text { Domeny: } \\
\text { D1: Błąd związany z procesem randomizacji } \\
\text { D2: Błąd związany z odstępstwem od planowanych interwencji } \\
\text { D3: Błąd związany z brakiem wyników } \\
\text { D4: Błąd związany z pomiarem wyników } \\
\text { D5: Błąd związany z doborem raportowanych wyników }\end{array}$} \\
\hline
\end{tabular}

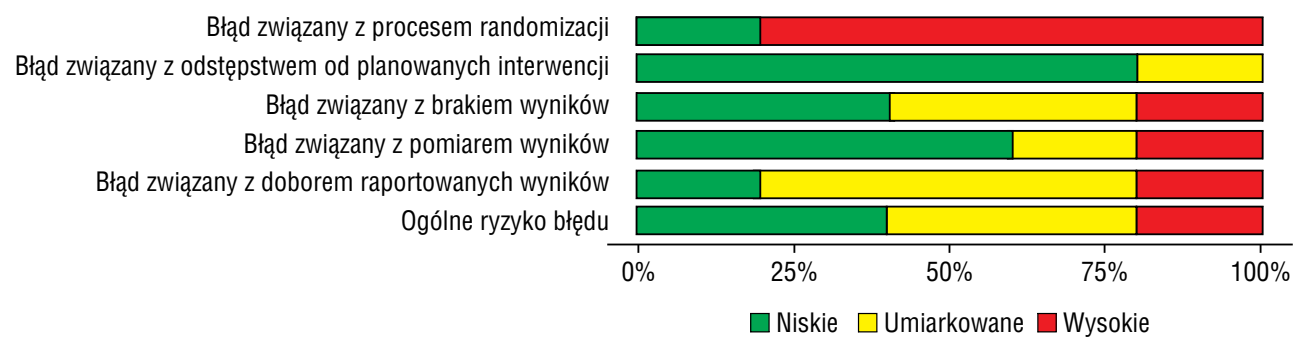

Rycina 2. Tabela ryzyka błędu systematycznego 
i wsp. była odpowiednia w odniesieniu do wieku, płci, wywiadu lekarskiego, badania fizykalnego i standardowych badań laboratoryjnych, ale brak kontynuacji i wysoki wskaźnik rezygnacji z badania doprowadziły do wystąpienia tak zwanego błędu utraty, który mógł wpłynąć na moc statystyczną badania i zmienić charakterystykę grup [3]. Ponadto wyniki tego badania nie zawierały wielu szczegółowych sprawozdań ze względu na małą liczebność próby, podobnie jak w badaniu Hosgood i wsp. [7]. Pompili i wsp. w swoim badaniu stwierdzili, że fenobarbital jest lekiem z wyboru w przypadku ciężkich napadów drgawkowych, ale dotyczyło ono tylko 30\% przypadków w badaniu, co prowadzi do obniżenia wiarygodności zewnętrznej i ogranicza możliwość uogólnienia na całą populację objętą opieką paliatywną [6]. Wyniki badania Sykes i wsp. również nie były reprezentatywne, gdyż nie badano wyłącznie roli fenobarbitalu w leczeniu napadów drgawkowych [4]. Inne środki uspokajające, w tym midazolam i lewomepromazyna, włączono do analizy statystycznej, co doprowadziło do uzyskania wyników, których nie można przypisać wyłącznie dziataniu fenobarbitalu. Ponadto w większości analizowanych badań brakowało analizy statystycznej. Jedynie Sykes i wsp. [4] oraz Lam i wsp. [3] podali wartości p w swoich badaniach. W związku z tym nie można było wyciągnąć wniosków na temat skuteczności fenobarbitalu. Stirling i wsp. stosowali fenobarbital nie tylko w leczeniu napadów drgawkowych, ale również w przypadku pobudzenia, co także może zafałszować wyniki dotyczące skuteczności fenobarbitalu w leczeniu napadów drgawkowych [1].

\section{Dyskusja}

\section{Mechanizm działania fenobarbitalu}

Fenobarbital jest znanym induktorem cytochromu P450 [11]. Enzymy te biorą udział $w$ metabolizmie wielu leków, co zwiększa ich klirens. W szczególności wykazano, że fenobarbital obniża stężenie w osoczu innych leków przeciwpadaczkowych, takich jak fenytoina i kwas walproinowy poprzez indukcję izoenzymu CYP3A4 [12]. Pomiędzy fenobarbitalem a kwasem walproinowym zachodzi istotna z klinicznego punktu widzenia interakcja. Kwas walproinowy jest słabym inhibitorem CYP3A4, a podczas jednoczesnego podawania z fenobarbitalem wykazano, że zwiększa on stężenie fenobarbitalu w osoczu [13]. Przy podawaniu kwasu walproinowego może być konieczne zmniejszenie dawki fenobarbitalu nawet o $80 \%$, aby uniknąć toksycznego działania leku [18]. Inna ważna interakcja lekowa występuje między fenobarbitalem a benzodiazepinami, na przykład midazolamem i diazepamem. Midazolam jest również metabolizowany przez CYP3A4, a przy jednoczesnym podawaniu z fenobarbitalem powoduje zwiększenie klirensu midazolamu [19]. Wykazano, że fenobarbital hamuje ośrodek oddechowy, zwłaszcza gdy jest podawany z opioidami lub benzodiazepinami, takimi jak midazolam [22]. Ważne jest, aby wziąć pod uwagę te interakcje podczas monitorowania dawki, w celu utrzymania dawki fenobarbitalu w zakresie terapeutycznym.

Z molekularnego punktu widzenia wykazano, że fenobarbital ogranicza aktywność koenzymu 1, znanego również jako dinukleotyd nikotynoamidoadeninowy (NADH, nicotinamide adenine dinucleotide), w łańcuchu transportu elektronów [16]. Uniemożliwia to wykorzystanie NADH jako substratu, co jest ważne dla czynności mitochondriów. Wywołane przez fenobarbital zaburzenia czynności mitochondriów powodują nasilenie stresu oksydacyjnego prowadzącego do śmierci komórek i kwasicy mleczanowej [17]. Kwasicę mleczanową można wykryć na podstawie badania stężednia dehydrogenazy mleczanowej (LDH, lactate dehydrogenase) w osoczu. Anderson i wsp. przeprowadzili badanie, które wykazało bezpośrednią korelację pomiędzy wysokim stężeniem LDH a neurotoksycznością wywołaną przez barbiturany, takie jak fenobarbital [16]. Wysokie stężenie LDH w badaniu kwasicy mleczanowej może wskazywać na uszkodzenie tkanek. Dlatego należy mieć na uwadze, że oprócz uszkodzenia tkanek fenobarbital może powodować także wzrost stężenia LDH.

\section{Rola fenobarbitalu w opiece paliatywnej}

W pięciu $z$ analizowanych badań potwierdzono skuteczność fenobarbitalu w opiece paliatywnej. W przeanalizowanych publikacjach łącznie 146 pacjentów było leczonych fenobarbitalem. Stirling i wsp. wykonali przegląd historii choroby wszystkich pacjentów, którzy otrzymali fenobarbital w ostatnim tygodniu życia w okresie 3 lat [1]. Dane te porównano z innymi pacjentami, którzy zmarli na oddziale w tym samym okresie. Skuteczność fenobarbitalu oceniano na podstawie retrospektywnej analizy historii choroby i równocześnie podawanych innych leków uspokajających. W grupie pacjentów, którym przepisano fenobarbital, istniała dokumentacje medyczna potwierdzająca jego skuteczność w porównaniu z innymi lekami uspokajającymi. W przypadku tego badania nie podano wartości $\mathrm{p}$ ani przedziału ufności, ponieważ nie przeprowadzono analizy statystycznej. Na podstawie historii choroby z ostatniego tygodnia życia 60 pacjentów, którym podawano fenobarbital metodą iniekcji podskórnej lub domięśniowej, bez istotnej różnicy między czasem od rozpoczęcia wlewu którąkolwiek z tych dróg do zgonu, stwierdzono, że 27 chorych otrzymywało fenobarbital z powodu 
pobudzenia, 3 z powodu cierpienia psychicznego, 20 z powodu pobudzenia i cierpienia psychicznego, a 9 z powodu napadów drgawkowych. W grupie, dla której wskazaniem podania leku były napady drgawkowe, po podaniu fenobarbitalu nie wystąpiły kolejne napady [1]. Nie obserwowano też niepożądanych reakcji skórnych [1].

Wykazano, że stosowanie fenobarbitalu w opiece paliatywnej wiąże się z obawami dotyczącymi stosowania leku jako środka uspokajającego i skracania czasu przeżycia (zasada podwójnego skutku). Ze względu na właściwości farmakokinetyczne fenobarbitalu nie opracowano zaleceń dotyczących dawek początkowych w opiece paliatywnej, jednak stosowanie mniejszych dawek (w razie potrzeby powtarzanych) może być korzystniejsze niż początkowe stosowanie maksymalnej zalecanej dawki [12]. Sykes i wsp. w swoim przeglądzie obejmującym 237 pacjentów wykazali, że nie ma to znaczenia, ponieważ 5 chorych było leczonych fenobarbitalem u schyłku życia [4]. Potwierdzono, że zwiększenie dawki fenobarbitalu w ostatnich godzinach życia do 200-500 mg/dobę w celu uzyskania uspokojenia polekowego nie wiązało się z reguły ze skróceniem przeżycia [4]. Grupa pacjentów, którzy otrzymywali fenobarbital jako środek uspokajający w odpowiednich dawkach przez mniej niż 48 godzin, miała najkrótsze przeżycie w porównaniu z grupą, która otrzymywała fenobarbital w tym samym celu przez ostatnie 7 dni (powyżej 48 godzin), u których średnie przeżycie wynosiło 36,6 dnia ( $p<0,001)$ [4]. Wykazano, że rozpoczęcie podawania fenobarbitalu w odpowiednich dawkach nie powodowało nagłego zgonu pacjenta, ponieważ był on podawany w ciągu ostatnich 7 dni życia. Jednak jeden pacjent leczony fenobarbitalem w dawce 200 mg podanej podskórnie zmarł 6 godzin po przyjęciu leku, podejrzewano, że fenobarbital przyczynił się do progresji zapalenia płuc u chorego na raka płuc pacjenta [4].

Pompili i wsp. przeprowadzili analizę roli opieki domowej dla pacjentów z glejakiem wielopostaciowym w latach 2012-2013 [6]. Liczba pacjentów z guzami mózgu wynosiła 197 osób, 122 pacjentów miało glejaka wielopostaciowego, 64 zmarło, zaś 54 było nadal leczonych. Stan tych pacjentów był okresowo oceniany za pomocą skali Barthel (Barthel Index), skali Karnofsky'ego (Karnofsky Performance Scale) oraz krótkiej skali oceny stanu psychicznego (Mini-Mental State Examination). Personel, który opiekował się tymi pacjentami składał się z 2 neurologów, 5 pielęgniarek, 2 psychologów, 3 rehabilitantów i 1 pracownika socjalnego. W miarę pogarszania się stanu zdrowia pacjenta zbliżającego się do kresu życia intensywność opieki ulegała należytej zmianie. W sumie odnotowano 2838 wizyt domowych i 11714 dni opieki, podczas których doszło do 34 zgonów w domu, 22 w hospicjum i 8 w szpitalu. Opieka domowa miała pozytywny wpływ na opiekunów i poprawę jakości życia u 72\% chorych ze względu na podejście wspierające ukierunkowane na edukację w zakresie opieki paliatywnej i łagodzenie stresu opiekunów [6]. W ostatnich tygodniach nie mierzono już samooceny jakości życia pacjentów z powodu znacznego upośledzenia funkcji poznawczych. W $11 \%$ przypadków zastosowano uspokojenie lekami w ramach opieki paliatywnej z użyciem midazolamu w celu uśmierzenia objawów, takich jak zespół majaczeniowy, pobudzenie, rzężenie przedśmiertne lub oporne na leczenie napady drgawkowe. W przypadku ciężkich napadów drgawkowych, które wystąpiły u 30\% chorych, lekiem z wyboru był fenobarbital podawany domięśniowo [6].

Wykazano, że właściwości farmakokinetyczne fenobarbitalu dają korzystne wyniki w kontrolowaniu ciężkich, opornych na leczenie napadów drgawkowych. Lam i wsp. przeprowadzili otwarte randomizowane badanie kliniczne z grupą kontrolną w układzie krzyżowym z udziałem 12 zdrowych osób dorosłych celem zbadania stężenia fenobarbitalu podawanego doodbytniczo w postaci mikrowlewek. Mikrowlewki podawano przy użyciu cewnika w postaci zawiesiny z pokruszonych tabletek doustnych fenobarbitalu 194,4 mg w 20 lub 6 ml wody. Porównywano działanie leku podanego $w$ ten sposób $z$ taką samą dawką fenobarbitalu przyjmowaną w postaci czopka [3]. Porównania dokonano, oceniając profil wczesnego wchłaniania równych dawek fenobarbitalu w czopku w porównaniu z lekiem w 20 i $6 \mathrm{ml}$ roztworach do mikrowlewek [3]. Wyniki badania wykazały, że średnie stężenie fenobarbitalu w osoczu po 10 minutach było 12-krotnie wyższe w przypadku zawiesiny w $20 \mathrm{ml}$ wody i 8-krotnie wyższe w przypadku zawiesiny w $6 \mathrm{ml}$ wody w porównaniu z lekiem przyjętym w czopku [3]. Średnie wartości AUC były wyższe dla zawiesiny w $20 \mathrm{ml}$ i $6 \mathrm{ml}$ wody (odpowiednio 82\% i 46\%) w porównaniu z czopkiem ( $p<0,05 \%$ ). Odnotowano również mniejszą zmienność wchłaniania zawiesin w 20 i $6 \mathrm{ml}$ wody (1,4-krotna różnica do 1,9-krotnej różnicy) w porównaniu z 4,4-krotną różnicą przy podawaniu leku w czopkach [3]. Wykazano, że tabletki doustne fenobarbitalu rozkruszone i zawieszone w wodzie, podane pacjentom za pomocą cewnika, mają większą skuteczność i mogą być łatwo podawane w porównaniu z czopkiem doustnym. Stwierdzono, że czopki z fenobarbitalem są zawodne i mają opóźniony początek działania w leczeniu napadów drgawkowych i cierpienia trudnego do opanowania w porównaniu z fenobarbitalem podawanym doodbytniczo $w$ formie zawiesiny w 20 i $6 \mathrm{ml}$ wody, które charakteryzowa- 
ły się mniejszą zmiennością i większym stężeniem w osoczu [3].

Amerykańska Inspekcja Farmaceutyczna (American Hospital Formulary Service) zaleca ostrożność przy podskórnym podawaniu fenobarbitalu ze względu na możliwe reakcje skórne. Hosgood i wsp. przeprowadzili badanie, w którym oceniono 69 pacjentów i 774 iniekcje podskórne fenobarbitalu [7]. Odnotowano dwie reakcje (2,9\% pacjentów, 0,3\% iniekcji), przy czym obie były łagodne (I stopień) i nie stanowiły przeszkody do dalszego podawania fenobarbitalu [7].

Fenobarbital był stosowany jako lek pomocniczy w terapii napadów drgawkowych, pobudzenia oraz w celach uspokajających. W badaniu poświęcono wiele uwagi drodze podania leku, czyli podskórnej, doodbytniczej oraz dożylnej. W każdym z analizowanych badań stwierdzono, że fenobarbital jest skuteczny w kontrolowaniu napadów drgawkowych i pobudzenia niezależnie od drogi podania. Niektórzy klinicyści uważają fenobarbital za lek pierwszego rzutu dla osiągnięcia uspokojenia polekowego w ramach opieki paliatywnej, podczas gdy inni stosują go jako opcję trzeciego rzutu, zapewniającą uspokojenie w przypadku niewystarczającej odpowiedzi na przeciwlękowe leki uspokajające i/lub lewomepromazynę. Fenobarbital ma długi czas działania z szybkim początkiem, według doniesień szybszym niż midazolam. Może być podawany dożylnie lub drogą ciągłego wlewu albo doraźnych iniekcji podskórnych. Działanie przeciwpadaczkowe fenobarbitalu może mieć dodatkowe znaczenie w leczeniu przeciwdrgawkowym [18]. Podsumowując, w przytoczonych badaniach analizowano zastosowanie fenobarbitalu w opiece paliatywnej. Wynika z nich, że fenobarbital jest niezawodnym, skutecznym środkiem w zwalczaniu pobudzenia oraz napadów drgawkowych i może być traktowany jako lek pierwszego rzutu.

\section{Podejście do leczenia napadów drgawkowych w różnych warunkach opieki paliatywnej}

W zależności od stanu zdrowia pacjenci objęci opieką paliatywną muszą podjąć decyzję w sprawie miejsca, w którym chcieliby przebywać w ostatnim okresie życia. Dostępne opcje to pobyt w szpitalu, hospicjum lub opieka domowa. Chorzy, u których występuje zespół majaczeniowy, pobudzenie, niepokój i napady drgawkowe, wymagają odpowiedniej kontroli objawów, aby osiągnąć maksymalny komfort w tym okresie. Benzodiazepiny podaje się często na wczesnym etapie leczenia paliatywnego, aby skrócić czas trwania napadów [19]. Midazolam jest najszerzej stosowanym lekiem pierwszego wyboru w łagodzeniu objawów zespołu majaczeniowego, pobudzenia i na- padów drgawkowych ze względu na jego działanie przeciwlękowe, przeciwdrgawkowe i uspokajające, który może być podawany podskórnie lub dożylnie. Jeśli midazolam nie wystarcza do kontroli objawów lub kontroluje je tylko częściowo, do terapii można włączyć fenobarbital. Istnieją jednak obawy, że midazolam potęguje działanie fenobarbitalu i zwiększa częstość występowania zespołu majaczeniowego i niewydolności oddechowej [22]. Fenobarbital jest lekiem z wyboru i może być stosowany dla osiągnięcia uspokojenia polekowego $w$ ramach opieki paliatywnej w celu opanowania niekontrolowanych objawów na wymaganym poziomie uspokojenia.

Pacjenci, u których występują ciężkie napady drgawkowe oporne na leczenie, mogą być leczeni fenobarbitalem podawanym podskórnie lub dożylnie przez przeszkolony personel medyczny. U pacjentów, którzy woleliby otrzymywać opiekę w domu, preferowanym rozwiązaniem byłoby stosowanie mikrowlewów doodbytniczych przy użyciu cewnika zamiast doustne podawanie leku (które może być utrudnione w zależności od przebiegu choroby) czy też podawanie podskórne lub dożylne. Stosowano również fenobarbital w postaci czopków, ale opóźniona reakcja związana z podaniem leku, dyskomfort i brak skuteczności sprawiają, że jest to mniej korzystna opcja niż mikrowlewy. Zawiesina pokruszonych tabletek fenobarbitalu w $20 \mathrm{ml}$ wody z kranu dawała najwyższe stężenie i skuteczność w porównaniu z zawiesiną leku w $6 \mathrm{ml}$ wody z kranu oraz lekiem podanym pod postacią czopka [3]. Mikrowlewy doodbytnicze byłyby idealnym rozwiązaniem dla pacjentów paliatywnych z ciężkimi napadami drgawkowymi, którzy woleliby otrzymywać opiekę w warunkach domowych.

W leczeniu objawowym pacjentów objętych opieką paliatywną stosuje się wiele leków. Działanie uspokajające tych leków dokładnie przestudiowano. Badania te wykazały istotną rolę fenobarbitalu w leczeniu napadów drgawkowych. Wykazano, że stosowanie leków uspokajających, takich jak midazolam, lewomepromazyna i fenobarbital w celu osiągnięcia uspokojenia, opanowania zespołu majaczeniowego, pobudzenia, niepokoju i napadów drgawkowych w ostatnich 7 dniach życia nie powoduje nagłego zgonu pacjenta. Ustalenie dawki terapeutycznej fenobarbitalu może być pomocne w sytuacjach trudnych do osiągnięcia odpowiedniej kontroli napadów drgawkowych przy zastosowaniu różnych dróg podawania leku: iniekcji dożylnej i podskórnej oraz mikrowlewki doodbytniczej. Stężenie leku może być mierzone w próbkach krwi, aby pomóc klinicystom w leczeniu napadów drgawkowych w warunkach opieki paliatywnej. 


\section{Ograniczenia}

W większości badań fenobarbital stosowano w terapii napadów drgawkowych, pobudzenia, niepokoju, a w niektórych do osiągnięcia uspokojenia polekowego w ostatnich 48 godzinach życia, a nie tylko do leczenia napadów drgawkowych. Stosowanie fenobarbitalu w skojarzeniu z innymi lekami uspokajającymi może wpływać na zgłaszane wyniki skuteczności kontroli napadów drgawkowych w ramach terapii fenobarbitalem. Aby zapewnić uwzględnienie w przeglądzie całości dostępnej literatury dotyczącej stosowania fenobarbitalu u pacjentów objętych opieką paliatywną, przeanalizowano zarówno prace recenzowane, jak i nierecenzowane. Jednakże publikacji nierecenzowanych nie poddano rygorystycznej analizie w celu zapewnienia wysokiej jakości badań, co mogło ograniczyć wiarygodność porównania tychże badań. Mała liczebność próby, krótki czas obserwacji lub jej brak przy braku standaryzacji wyników stwarzają ryzyko wystąpienia błędu systematycznego w ocenie skuteczności fenobarbitalu w terapii napadów drgawkowych pacjentów objętych opieką paliatywną. Brak randomizowanych badań klinicznych z grupą kontrolną utrudnia stwierdzenie, czy istnieje związek przyczynowo-skutkowy między terapią fenobarbitalem a wynikiem leczenia. Przy braku statystycznie istotnych wyników wnioski dotyczące fenobarbitalu nie mogą być uznane za bezsporne. Ponieważ populacja włączona do jedynego randomizowanego badania klinicznego z grupą kontrolną obejmowała 12 zdrowych dorosłych, w badaniu nie oceniano skuteczności fenobarbitalu w kontrolowaniu napadów drgawkowych [3].

\section{Wnioski}

Fenobarbital jest niezawodnym i skutecznym lekiem w terapii napadów drgawkowych i pobudzenia. Jest to wydajny lek, który wykazuje dużą siłę działania w łagodzeniu objawów u pacjentów objętych opieką paliatywną. Fenobarbital może być stosowany, gdy podawanie leku drogą doustną nie wchodzi w grę, a droga dożylna jest niedostępna lub niepożądana. Fenobarbital może być stosowany w terapii ciężkich napadów drgawkowych na podłożu wieloczynnikowym. Różnorodność dostępnych dróg podawania (podskórna, dożylna, domięśniowa i doodbytnicza) sprawia, że fenobarbital jest idealnym rozwiązaniem w różnych warunkach opieki paliatywnej. Mimo że fenobarbital cechuje działanie uspokajające, nie wykazano, aby stosowanie leku w odpowiednich dawkach przyczyniało się do nagłego zgonu pacjentów. Fenobarbital może być stosowany w opiece paliatywnej w celu opanowania zespołu majaczeniowego, pobu- dzenia, niepokoju i napadów drgawek oraz na potrzeby osiągnięcia uspokojenia polekowego ze względu na działanie uspokajające i przeciwdrgawkowe.

Należy jednak zaznaczyć, że stosowanie fenobarbitalu w terapii napadów drgawkowych i w celu osiągnięcia uspokojenia polekowego nie było przedmiotem szeroko zakrojonych badań. Ograniczona liczba badań może być niewystarczająca, aby pozwolić na wyciągnięcie uogólnionych wniosków dotyczących stosowania fenobarbitalu we wszystkich kontekstach opieki paliatywnej. Aby zebrać więcej danych dotyczących praktycznego zastosowania fenobarbitalu, konieczna jest analiza recenzowanych i nierecenzowanych publikacji w celu zrozumienia pełnego zakresu działania leku u schyłku życia pacjenta. W celu zminimalizowania błędu systematycznego potrzebne są badania zawierające istotne statystycznie wyniki, które potwierdzą skuteczność fenobarbitalu w opiece paliatywnej. Do oceny skuteczności fenobarbitalu w terapii napadów drgawkowych i pobudzenia potrzebne są randomizowane badania kliniczne z grupą kontrolną z większą liczebnością próby i dłuższym okresem obserwacji. Randomizacja i dobór grupy pacjentów objętych opieką paliatywną, u których występują napady drgawkowe i pobudzenie z powodu różnych stanów chorobowych niezależnie od wieku, w okresie co najmniej 2 lat, może pomóc w ustaleniu roli fenobarbitalu w opiece paliatywnej. Próba licząca co najmniej 200 chorych z różnych ośrodków opieki paliatywnej może pomóc w ocenie skuteczności różnych dróg podawania fenobarbitalu, to jest podskórnej, dożylnej i doodbytniczej, oraz w ustaleniu, czy ten sposób podawania jest rzeczywiście skuteczny w leczeniu napadów drgawkowych i pobudzenia u schyłku życia. Klinicyści, pielęgniarki i badacze mogą współpracować przy przepisywaniu, gromadzeniu i ocenie danych w celu dalszej ewaluacji skuteczności fenobarbitalu. Usunięcie istniejących wątpliwości przyczyniłoby się do poszerzenia wiedzy na temat stosowania fenobarbitalu u pacjentów objętych opieką paliatywną.

\section{Podziękowania}

Autorzy pragną podziękować Nida Amatul MD, Nuzla Ameen MD i Ryan Johal MD za ich wkład w napisanie i edycję tego manuskryptu.

\section{Deklaracja konfliktu interesów}

Autorzy oświadczają, że nie występuje konflikt interesów.

\section{Finansowanie}

To badanie nie zostało sfinansowane. 


\section{Piśmiennictwo}

1. Stirling LC, Kurowska A, Tookman A, et al. The use of phenobarbitone in the management of agitation and seizures at the end of life. J Pain Symptom Manage. 1999; 17(5): 363-368, doi: 10.1016/s0885-3924(99)00006-8, indexed in Pubmed: 10355215.

2. Tradounsky G. Seizures in palliative care. Can Fam Physician. 2013; 59(9): 951-5, e401, indexed in Pubmed: 24029509.

3. Lam YW, Lam A, Macy B, et al. Pharmacokinetics of Phenobarbital in Microenema Via Macy Catheter Versus Suppository. J Pain Symptom Manage. 2016; 51(6): 994-1001, doi: 10.1016/j.jpainsymman.2015.12.339, indexed in Pubmed: 27112311.

4. Sykes N, Thorns A. Sedative use in the last week of life and the implications for end-of-life decision making. Arch Intern Med. 2003; 163(3): 341-344, doi: 10.1001/archinte.163.3.341, indexed in Pubmed: 12578515.

5. Yasiry Z, Shorvon SD. How phenobarbital revolutionized epilepsy therapy: the story of phenobarbital therapy in epilepsy in the last 100 years. Epilepsia. 2012; 53 Suppl 8: 26-39, doi: 10.1111/epi.12026, indexed in Pubmed: 23205960.

6. Pompili A, Telera S, Villani V, et al. Home palliative care and end of life issues in glioblastoma multiforme: results and comments from a homogeneous cohort of patients. Neurosurg Focus. 2014; 37(6): E5, doi: 10.3171/2014.9.FOCUS14493, indexed in Pubmed: 25434390.

7. Hosgood JR, Kimbrel JM, McCrate Protus B, et al. Evaluation of Subcutaneous Phenobarbital Administration in Hospice Patients. Am J Hosp Palliat Care. 2016; 33(3): 209-213, doi: 10.1177/1049909114555157, indexed in Pubmed: 25473092.

8. Griebling TL, Kachru N, Carnahan RM, et al. By the 2019 American Geriatrics Society Beers Criteria ${ }^{\circledR}$ Update Expert Panel, By the American Geriatrics Society 2015 Beers Criteria Update Expert Panel. American Geriatrics Society 2015 Updated Beers Criteria for Potentially Inappropriate Medication Use in Older Adults. J Am Geriatr Soc. 2015; 63(11): 2227-2246, doi: 10.1111/jgs.13702, indexed in Pubmed: 26446832.

9. Waller DG, Sampson AP. Pharmacol Ther. 2018: 311-323, doi: 10.1016/b978-0-7020-7167-6.00023-3.

10. Kale $R$, Perucca E. Revisiting phenobarbital for epilepsy. BMJ. 2004; 329(7476): 1199-1200, doi: 10.1136/bmj.329.7476.1199, indexed in Pubmed: 15550407.

11. Czekaj P. Phenobarbital-induced expression of cytochrome P450 genes. Acta Biochim Pol. 2000; 47 (4): 10931105. PMID: 11996099.
12. Brodie MJ, Mintzer S, Pack AM, et al. Enzyme induction with antiepileptic drugs: cause for concern? Epilepsia. 2013; 54(1): 11-27, doi: 10.1111/j.1528-1167.2012.03671.x, indexed in Pubmed: 23016553.

13. Perucca E. Clinically relevant drug interactions with antiepileptic drugs. Br J Clin Pharmacol. 2006; 61(3): 246-255, doi: 10.1111/j.1365-2125.2005.02529.x.

14. Tradounsky G. Seizures in palliative care. Can Fam Physician. 2013; 59(9): 951-5, e401, indexed in Pubmed: 24029509.

15. Grönheit W, Popkirov S, Wehner T, et al. Practical Management of Epileptic Seizures and Status Epilepticus in Adult Palliative Care Patients. Front Neurol. 2018; 9: 595, doi: 10.3389/fneur.2018.00595, indexed in Pubmed: 30116217.

16. Anderson CM, Norquist BA, Vesce $S$, et al. Barbiturates induce mitochondrial depolarization and potentiate excitotoxic neuronal death. J Neurosci. 2002; 22 (21): 9203-9209, indexed in Pubmed: 12417645.

17. Olszewska A, Szewczyk A. Mitochondria as a pharmacological target: magnum overview. IUBMB Life. 2013; 65(3): 273-281, doi: 10.1002/iub.1147, indexed in Pubmed: 23441041.

18. Wen X, Wang JS, Kivistö KT, et al. In vitro evaluation of valproic acid as an inhibitor of human cytochrome P450 isoforms: preferential inhibition of cytochrome P450 2C9 (CYP2C9). Br J Clin Pharmacol. 2001; 52(5): 547-553, doi: 10.1046/j.0306-5251.2001.01474.x, indexed in Pubmed: 11736863.

19. Favié LMA, Groenendaal F, van den Broek MPH, et al. on behalf of the PharmaCool study group. Phenobarbital, Midazolam Pharmacokinetics, Effectiveness, and Drug-Drug Interaction in Asphyxiated Neonates Undergoing Therapeutic Hypothermia. Neonatology. 2019; 116(2): 154-162, doi: 10.1159/000499330, indexed in Pubmed: 31256150.

20. Bush SH, Tierney S, Lawlor PG. Clinical Assessment and Management of Delirium in the Palliative Care Setting. Drugs. 2017; 77(15): 1623-1643, doi: 10.1007/s40265017-0804-3, indexed in Pubmed: 28864877.

21. Bartz L, Klein C, Seifert A, et al. Subcutaneous administration of drugs in palliative care: results of a systematic observational study. J Pain Symptom Manage. 2014; 48(4): 540-547, doi: 10.1016/j.jpainsymman.2013.10.018, indexed in Pubmed: 24766744.

22. Cheng $C$, Roemer-Becuwe $C$, Pereira J. When midazolam fails. J Pain Symptom Manage. 2002; 23(3): 256-265, doi: 10.1016/s0885-3924(01)00412-2, indexed in Pubmed: 11888723. 